\title{
KARAKTERISTIK HUBUNGAN \\ MUHAMMADIYAH DAN NU DALAM \\ MENGGUNAKAN HISAB DAN RUKYAT
}

\section{Susiknan Azhari}

Fakultas Syari'ah Universitas Islam Negeri Sunan Kalijaga Yogyakarta

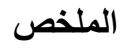

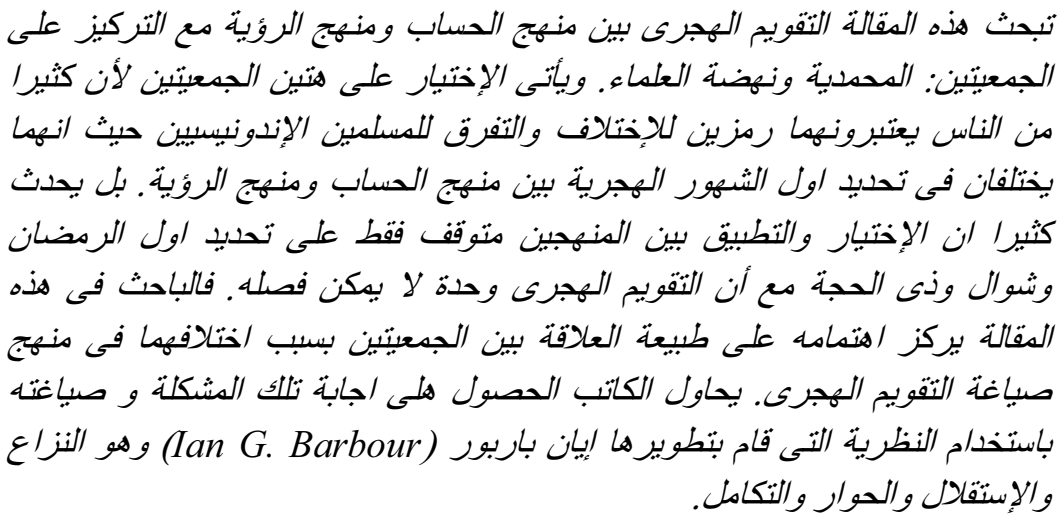

\section{Abstract}

This article studies the matter of hisāb and ru'ya, particularly conducted by the following two extremely well-known socio-religious organizations, $N U$ and Mubammadiyah. The reason for this choice is that the two for most of Indonesian people is the symbol of difference, even, of dissension among its Muslims referring to the thought of lunar calendar in Indonesia. The choice and the usage of the two matters frequently take place to determine the beginning of Ramaḍān, Shawwāl and Dhū'l-Hijja in spite of the others. Therefore, it is necessary to deal with how the relation between $N U$ and Mubammadiyah is due to the matters. To find out the answer for 
the inquiry theoretical framework developed by Ian G. Barbour i.e.: Conflict, Independent, Dialogue and Integration will be exercised.

Key Words: Hisāa, Ru'ya, NU, and Muhammadiyah

\section{A. Pendahuluan}

"Waktu saya di Mesir, anak-anak NU dan Mubammadiyah sama-sama belajar di satu tempat. Saya berkesimpulan, perbedaan antara NU dan Mubammadiyah di masa depan tidak akan ada lagi. Selama ini, Muhammadiyah pembaru, NU tradisional, yang akan terjadi, dua-duanya tradisional atau dua-duanya pembaru." (Harun Nasution). ${ }^{1}$

Di Indonesia, organisasi-organisasi keagamaan terutama Nahdlatul Ulama ${ }^{2}$ dan Muhammadiyah ${ }^{3}$ (selanjutnya disebut NU dan Muhammadiyah) ketika berinteraksi dengan persoalan Kalender Hijriah telah berkiprah dan memberi corak sesuai doktrin yang dimiliki; khususnya dalam penetapan awal bulan Ramadan, Syawal dan Zulhijah. Corak doktrin ini pada masa Orde Baru melahirkan ketegangan teologis dan tampak mewarnai perbedaan Hari Raya di kalangan NU dan Muhammadiyah. ${ }^{4}$

\section{hlm. 13.}

${ }^{1}$ Baca Panji Masyarakat, No. 619, 19-29 Zulhijah 1409/ Juli - 1 Agustus 1989,

${ }^{2}$ Nahdlatul Ulama didirikan pada 1926 M/ 1345 H oleh sejumlah tokoh ulama tradisional dan usahawan Jawa Timur. Pembentukannya seringkali dijelaskan sebagai reaksi defensif terhadap berbagai aktivitas kelompok reformis. Lihat Martin van Bruinessen, NU Tradisi Relasi-relasi Kuasa Pencarian Wacana Baru, terjemahan Farid Wajidi, cet. II (Yogyakarta: LKiS, 1997), hlm. 17. Lihat juga Andree Feilard, NU vis-a-vis Negara Pencarian Isi, Bentuk dan Makna, cet. I, (Yogyakarta: LKiS, 1999).

${ }^{3}$ Muhammadiyah sejak berdirinya, dikenal sebagai pelopor pembaharuan pemikiran Islam khususnya di Indonesa, baik yang bercorak purifikatif (pemurnian di bidang akidah-ibadah) maupun rasionalistik (bidang muamalah duniawiyah). Baca Hamim Ilyas (ed.), Pengembangan Pemikiran Keislaman Mubammadiyab: Purifikasi \& Dinamisasi, cet. I (Yogyakarta: Majelis Tarjih PPI \& LPPI, 2000), hlm. v.

${ }^{4}$ Tak jarang perbedaan itu menjadi penyebab perseteruan dan mengusik ukhuwah di antara sesama muslim gara-gara melakukan suatu peribadatan tidak sama. Hal ini bisa dilihat beberapa kasus "lebaran kembar" yang mencuat ke permukaan, misalnya tahun 1405 H/1985 M, 1412 H/1992 M, 1413 H/1993 M, 1414 H/1994 M,1418 H/ 1998 M, dan 1422 H/2002 M. Berdasarkan perhitungan ahli hisab kasus semacam ini akan terulang pada tahun 2006, 2007, 2008, 2010, 2019 dan 2020 M mendatang. 
Bukan rahasia lagi bahwa NU dan Muhammadiyah bagi banyak kalangan merupakan simbol perbedaan, bahkan perpecahan, di kalangan umat Islam Indonesia. ${ }^{5}$ Tentu saja cara pandang seperti ini banyak mengundang gugatan dan pertanyaan yang serius. Meskipun perbedaan, dan barangkali juga perpecahan itu, pernah demikian mencekam, ${ }^{6}$ namun dalam proses-proses lebih lanjut akhirnya masyarakat menyadari bahwa perbedaan atau perpecahan itu hanya ada dalam wujud lahiriah saja dan tidak pernah menyentuh persoalan-persoalan prinsip yang diperkirakan akan "mengganggu" substansi keislaman masing-masing. Jelas sekali bahwa sikap-sikap "takfir" antara para pendukung kedua organisasi terbesar Islam di Indonesia itu sudah dianggap tidak relevan dalam wacana kontemporer. ${ }^{7}$

Jadi, persoalannya memang bukan perbedaan atau pertentangan, tapi bagaimana memahami hubungan keduanya dalam suatu desain doktrin-doktrin keagamaan, khususnya yang terkait dengan pemikiran

${ }^{5}$ Muhammadiyah dipandang sebagai kelompok umat Islam puritan (modernis), sementara NU dipandang sebagai kelompok umat Islam konservatif atau tradisional. Lihat Adam Schwarz, Islam: Coming in from the Cold dalam bukunya, A Nation in Waiting, Indonesia in The 1990's, (Sydney: Allan and Unwin, 1994), p. 171. Lihat pula Deliar Noer, Gerakan Modern Islam di Indonesia 1900-1942, cet. I (Jakarta: LP3ES, 1980). Sementara itu, menurut A. Mukti Ali, NU dipandang sebagai kelompok modernis. Karena salah satu ciri yang khas bagi masyarakat Islam modern di Indonesia adalah adanya organisasi. Lihat A. Mukti Ali, Alam Pikiran Islam Modern di Indonesia, (Yogyakarta: Jajasan NIDA, 1969), hlm. 5.

"Perhatikan misalnya, “Tragedi Idul Fitri 1969". Gara-gara konflik teologis, pendukung rukyat dan hisab terlibat konflik fisik dan jatuh korban nyawa. Uraian selengkapnya lihat Panji Masyarakat, No. 612, 15-25 Syawal 1409 H, 21-31 Mei 1989, hlm. 73-75.

${ }^{7}$ Dalam artikelnya berjudul "Muhammadiyah dan NU: Bersaudara dalam Perbedaan" A. Syafi'i Maarif antara lain menulis: Terus terang kita merasa ngeri bilamana kita sampai terjerembab ke jurang kafir-mengkafirkan itu. Bila kita mau jujur, sebenarnya yang paling tahu di mana posisi hati kita berhadapan dengan masalah iman hanyalah Allah, karena Ialah yang menciptakan betapa rumitnya masalah hati.... Oleh karena itu untuk menegak.kan budaya "bersaudara dalam perbedaan", sifat saling mengkafirkan lantaran perbedaan dalam memahami prinsip-prinsip agama wajib dibindari......Lihat A. Syafi'i Maarif, Peta Bumi Intelektualisme Islam di Indonesia, cet. III (Bandung: Mizan, 1995), hlm. 239. Perhatikan pula rekaman pengajian bersama NU dan Muhammadiyah pada tanggal 26 September 1999 di Gedung Pusat Dakwah Pimpinan Pusat Muhammadiyah Jakarta dalam casette Menuju Indonesia Baru Muhammadiyah dan Nabdlatul Ulama Bersatu produksi Dian Records. 
Kalender Hijriah. Kaitannya dengan pemikiran Kalender Hijriah, perbedaan yang nampak antara NU dan Muhammadiyah terletak pada hisab dan rukyat. Bahkan yang sering terjadi, pemilihan dan penggunaan hisab dan rukyat tersebut hanya terfokus pada awal Ramadan, Syawal dan Zulhijah, sehingga sering muncul perbedaan, padahal Kalender Hijriah merupakan satu kesatuan. Oleh karena itu, studi ini ingin melihat hubungan yang terjadi antara NU dan Muhammadiyah dalam memformulasi Kalender Hijriah, khususnya dalam menggunakan hisab dan rukyat untuk menetapkan awal dan akhir Ramadan.

\section{B. Pandangan NU dan Muhammadiyah tentang Hisab dan Rukyat}

Hasil penelitian Izzuddin menyebutkan bahwa pembahasan persoalan hisab dan rukyat di kalangan NU telah dimulai sejak Muktamar NU ke-20 di Surabaya pada tanggal 10-15 Muharam 1374 H/ 8-13 September 1954 M. Ketika itu, pembahasan persoalan hisab dan rukyat berawal dari pertanyaan Pengurus Cabang NU Banyuwangi tentang hukum mengumumkan awal Ramadlan atau awal Syawal untuk umum dengan hisab atau orang yang mempercayai sebelum ada penetapan hakim atau siaran dari Departemen Agama. ${ }^{8}$

Pertanyaan itu dijawab dalam Muktamar NU ke-20 di Surabaya dengan merujuk kitab Al-Bughyah halaman 110 dan kitab al-Fatāwa alKubra jilid V halaman 164, sebagai berikut:

Sesungguhnya mengkabarkan tetapnya awal Ramadhan atau awal Syawal dengan hisab itu tidak terdapat di waktu Rasulullah dan Khulafaur Rasyidin. Sedang pertama-tama orang yang membolehkan puasa dengan hisab ialah: Imam Muththarif guru Imam al-Bukhari. Adapun mengumumkan tetapnya awal Ramadhan atau Syawal berdasarkan hisab sebelum ada penetapan/ siaran dari Departemen Agama, maka muktamar memutuskan tidak boleh, sebab untuk menolak kegoncangan dalam kalangan umat Islam, dan muktamar mengharap kepada pemerintah supaya melarangnya. ${ }^{9}$

${ }^{8}$ Selengkapnya baca Ahmad Izzuddin, Figh Hisab Rukyah di Indonesia, cet. I, (Yogyakarta: LOGUNG, 2003), hlm. 94.

${ }^{9}$ Ibid. 
Selanjutnya, persoalan hisab dan rukyat tersebut dikaji ulang pada Muktamar NU ke-27 di Situbondo, 1984 M/ 1405 M, Munas Alim Ulama di Cilacap 1987 M/ 1408 H, dan Rapat Kerja Lajnah Falakiah PB NU di Pelabuhan Ratu 1992 M/1412 H. Hasil pertemuan tersebut memutuskan bahwa kaitannya dengan persoalan Kalender Hijriah, khususnya dalam penetapan awal Ramadan dan Syawal, NU mendasarkan pada rukyatul hilal dan istikmal. Karena rukyatul hilal dan istikmal dianggap memiliki sanad yang jelas melalui kitab-kitab yang muktabar. ${ }^{10}$

Bagi NU kedudukan hisab hanya sebagai pembantu dalam pelaksanaan rukyatul hilal di lapangan. Oleh karena itu, meski sudah melakukan prediksi, mereka tidak berani memastikan awal bulan Ramadan, Syawal, dan Zulhijah dengan hisab, tetapi tetap menunggu hasil rukyat di lapangan. Seperti telah diketahui, NU mengulang-ulang hadis Nabi saw sümū li ru'yatibi sebagai justifikasi. Mereka mengakui bahwa kata hilal (newmoon) yang terdapat dalam Q.S. al-Baqarah ayat 189 bersifat general. Akan tetapi, kaitannya dengan awal Ramadan dan Syawal, hadis-hadis rukyat dianggap paling tegas dan jelas sebagai landasan beristimbat. ${ }^{11}$ Tegasnya, rukyat merupakan landasan utama bagi NU dalam menetapkan awal dan akhir Ramadan. ${ }^{12}$

Sikap NU juga sama dengan yang berkembang di negara Saudi Arabia, ${ }^{13}$ Syiria, ${ }^{14}$ Maroko, ${ }^{15}$ dan Bahrain. ${ }^{16}$ Syaikhul Islam Ibn Taimiyah,

\footnotetext{
${ }^{10}$ Selengkapnya baca Irfan Zidny. "Memahami Cara NU dalam Penetapan 1 Syawal", dimuat dalam harian Jawa Pos, Rabu Pahing, 9 Maret 1994, hlm. 4. Perhatikan pula dengan Ahmad Zahro, Lajnah Babtsul Masail Nabdlatul Ulama 1926-1999 (Telaah Kritis Terhadap Keputusan Hukum Fiqib), (Yogyakarta: Disertasi Program Doktor IAIN Sunan Kalijaga Yogyakarta, 2001), hlm. 135-150. Bandingkan pula A. Malik Madaniy, "Penentuan Awal Bulan Qamariyah Sepanjang Ketentuan Syara", dimuat dalam Jurnal Asy-Syir'ah, Vol. 37, No. II, Th. 2003, hlm. 7.

${ }^{11}$ Wawancara dengan Muhyiddin pada tanggal 3 November 2000 di Yogyakarta.

${ }^{12}$ Selengkapnya baca PB NU, Pedoman Hisab dan Rukyat, Jakarta: Lajnah Falakiyah PB NU, 1994), hlm. 2.

${ }^{13}$ Menurut Zaki al-Mostafa salah seorang yang bertanggungjawab terhadap kalender Ummul Qura menyatakan bahwa sejak tahun 1423 H Saudi Arabia dalam menentukan awal bulan kamariah menggunakan teori miladul bilal artinya ijtimak terjadi sebelum ghurub dan matahari terbenam terlebih dahulu dibandingkan bulan. Teori ini hampir sama dengan teori wujudul hilal Muhammadiyah.
} 
sebagaimana dikutip Nurcholish Madjid, juga mendukung penggunaan rukyat. Karena menurutnya, ilmu hisab meskipun secara logika kebenarannya dapat dipercaya dan mendekati kebenaran dibandingkan ilmu-ilmu yang lain, namun ia tetap memiliki keterbatasan dalam menangkap pesan ilahi, khususnya untuk menentukan awal bulan kamariah (awal Ramadan dan Syawal). Ibn Taimiyah menegaskan bahwa nalar deduksi tidak akan membawa kebahagiaan manusia. ${ }^{17}$ Argumentasi Ibn Taimiyah ini dapat dimaklumi karena pada saat itu orang sudah melupakan hukum-hukum agama dan mendewakan ilmuilmu yang positifistik. Jadi, posisinya bukan menjustifikasi benar atau salah melainkan ingin mengembalikan ilmu ke pangkalnya (al-Qur'an dan as-Sunnah). Begitu pula, Syekh Abdullah bin Baz, Ketua Lajnah Daimah untuk Riset Ilmiah dan Fatwa Saudi Arabia, berpendapat bahwa untuk memulai awal Ramadan dan Syawal hanya dengan rukyat atau istikmal. Hal ini didasarkan hadis sahih, "berpuasalah karena melihatnya (hilal), dan berbukalah karena melihatnya (hilal), namun jika tertutup awan maka sempurnakanlah bulan Syakban tiga puluh hari. Selanjutnya, Abdullah bin Baz menganggap penggunaan ilmu falak (hisab) dalam menetapkan awal Ramadan dan Syawal termasuk bid'ah yang tidak ada kebaikan di dalamnya, juga tidak mempunyai landasan dalam syari'at. Dalam uraiannya Abdullah bin Baz menjelaskan:

Di sini Rasulullah saw. menetapkan puasa dengan melihat hilal Ramadan dan berhari raya dengan melihat hilal Syawal, dan beliau tidak berpedoman dengan hisab perbintangan dan peredaran planet. Demikianlah yang dilakukan di masa Nabi saw, khulafaur rasyidin, imam yang empat, dan tiga abad yang dikatakan Rasulullah sebagai zaman

${ }^{14}$ Wawancara dengan Basil Tamim pada tanggal 27 Ramadan 1425 H/ 10 Nopember 2004 M di Universitas Madinah.

${ }^{15}$ Dilaporkan oleh Buitelaar dalam disertasinya yang berjudul Fasting ang Feasting in Morocco An Ethnographic Study of The Month of Ramadan (1991) sebagaimana dikutip oleh André Moller.

${ }^{16}$ Al-Ittihad, 13 Nopember 2004, hlm. 1.

${ }^{17}$ Nurccholish Madjid, Ibn Taymiyya on Kalam and Falsafa (A Problem of Reason and Revelation in Islam), (Chicago: A Dissertation Submitted to The Faculty of Division on The Humanities in Candidacy for The Degree of Doctor of Philosophy, 1984), hlm. 235-236; Ibn Taymiyya, Al-Radd' 'ala al-Mantiqiyyin, (Bombay: Sharaf al-Din al-Kutubi wa Awladah, 1368/1949), hlm. 264-265. 
terbaik. Menetapkan bulan qamariyah dengan ilmu falak dalam memulai ibadah dan mengakhirinya tanpa ru'yah termasuk bid'ah yang tidak ada kebaikan di dalamnya, juga tidak mempunyai landasan dalam syari'at. Oleh karena itu, Kerajaan Saudi Arabia berpegang kepada apa yang telah dicontohkan Rasulullah dan para salafussalih dalam hal penetapan puasa dan hari raya serta waktu-waktu haji yaitu melihat hilal. ${ }^{18}$

Menurut Abdullah Bin Baz, pendapatnya tersebut telah disetujui oleh Dewan Ulama Senior di Kerajaan Saudi Arabia, ${ }^{19}$ sehingga hampir semua ulama di Saudi Arabia berpendapat bahwa hisab adalah bid'ah. ${ }^{20}$

Sementara itu, Muhammadiyah mempertautkan antara dimensi ideal wahyu dan peradaban manusia. Karena itu, dalam menetapkan awal Ramadan dan Syawal, Muhammadiyah tidak semata-mata dengan rukyat tapi juga menggunakan hisab. ${ }^{21}$ Bagi Muhammadiyah yang mengembangkan nalar rasional-ilmiah, rukyat tidak semata-mata dipahami secara literal-parsial, tetapi didialogkan dengan ayat-ayat terkait, seperti Q.S. al-Baqarah ayat 185 dan Q.S. Yunus ayat 5, sehingga metodologi yang dikembangkan Muhammadiyah dalam menetapkan awal bulan kamariah sangat elastis-produktif atau dalam bahasa Nashr Hamid Abu Zaid diistilahkan dengan al-Qirāah al-Muntijah. ${ }^{22} \mathrm{Hal}$ ini

${ }^{18}$ Abdullah bin Baz, Kumpulan Fatwa Puasa, terjemahan Anshari Taslim dan E. Rukmana, (Jakarta: Khairul Bayan, 2003), hlm. 15.

${ }^{19} \mathrm{Ibid}$, hlm. 7

${ }^{20}$ Kenyataan ini penulis temukan saat melakukan penelitian di Saudi Arabia. Buku-buku yang membicarakan persoalan puasa menyebutkan bahwa untuk memulai dan mengakhiri puasa dengan rukyat dan hisab hukumnya bidah. Selengkapnya baca Muhammad bin Salih al-Al-Munjid, Mas'alah fi as-Siyami, (Riyadh: Markaz Khidmah al-Mutabarain bi al-Kitab, $1425 \mathrm{H})$, hlm. 4.

${ }^{21}$ Djarnawi Hadikusuma, "Mengapa Muhammadiyah Memakai Hisab ?”, Suara Mubammadiyah, No. I, Th. Ke-53, DZulhijah 1392/ Januari 1973; Susiknan Azhari, "Penentuan Awal Ramadan dan Syawal Model Muhammadiyah", Suara Mubammadiyah, No. 23 Th. Ke-85, hlm. 37 - 38. Patut diketahui dalam Keputusan Tarjih yang telah menjadi tuntunan, pada kitab Shiyam dalam judul Kaifiyah Shiyam, ada 4 cara yang dapat ditempuh oleh Muhammadiyah dalam menentukan awal dan akhir puasa Ramadan, yaitu (1) Rukyatul Hilal, (2) Mendengarkan persaksian orang yang adil, (3) Istikmal, dan (4) Hisab. Selengkapnya baca Asjmuni Abdurrahman, "Menentukan Awal Bulan Ramadan, dan Syawal Berdasar Hisab Termasuk Bid'ah?", Suara Muhammadiyah, No. 1, Tahun ke-89, 1 - 15 Januari 2004 M/23 Zulqa'dah 1424 H, hlm. 24-25.

${ }^{22}$ Nașr Hamid Abū Zayd, Naqd al-Khitāab al-Diniy, hlm. 144 dan 197. 
diperkuat dengan data historis bahwa penentuan awal bulan kamariah tidak semata-mata dengan rukyat tapi bisa menggunakan hisab. Asjmuni Abdurrahman dalam uraiannya menyebutkan:

Penentuan awal bulan Ramadan maupun Syawal dengan hisab bukanlah pada masa sekarang saja. Kalau kita membuka kitab Bidayatul Mujtahid susunan Ibn Rusyd seorang ulama mazhab Maliki (520-595 H/1126$1198 \mathrm{M}$ ), akan kita dapati bahwa penggunaan hisab oleh sebagian ulama sejak masa sahabat atau tabi'in. Dalam kitab ini dinyatakan bahwa penentuan awal bulan kalau dilakukan rukyat tidak terlihat karena mendung, maka dengan melakukan hisab. Hal ini telah dilakukan oleh sebagian ulama salaf, dalam hal ini dipelopori oleh tokoh senior tabi'in yang bernama Matarif bin asy-Syahr. Oleh sebagain ulama Syafi'iyyah dinyatakan bahwa ahli hisab dan yang mempercayai (kebenaran perhitungannya) wajib melakukan puasa berdasarkan pada hisabnya. ${ }^{23}$

Kutipan di atas sejalan dengan uraian yang terdapat pada Ensiklopedi Islam yang menyebutkan:

Di antara ulama yang tertarik untuk menentukan awal atau akhir bulan Ramadan dengan hisab itu adalah Ibnu Banna, Ibn Suraij, al-Qaffal, Kadi Abu Taib, Ibnu Qutaibah, Ibnu Muqatil ar-Razi, Ibnu Daqiq alId, dan Subki. Sementara itu ulama abad ke-20 yang cenderung mempergunakan hisab dalam menentukan awal atau akhir bulan Ramadan ialah Muhammad Rasyid Rida dan Tantawi Jauhari. ${ }^{24}$

Pola pemikiran Muhammadiyah di atas sama dengan yang berkembang di Pakistan, ${ }^{25}$ Tajikistan, ${ }^{26}$ Mesir, ${ }^{27}$ Saudi Arabia (pasca

${ }^{23}$ Asjmuni Abdurrahman, "Penentuan Awal Bulan Ramadlan dan Satu Syawal", Suara Mubammadiyah, No. 17/Th. Ke-83 (1-15 September 1998), hlm. 31. Baca juga Ibn Rusyd, Bidāyatu al-Mujtahid wa Nihāyatu al Muqtașid, (Beirut: Dār al-Fikr, t.t), I: 208.

${ }^{24}$ A. Hafidz Dasuki, dkk, Ensiklopedi Islam, cet. I (Jakarta: Ichtiar Van Hoeve, 1994), Jilid 2, hlm. 119. Baca juga Tantawy al-Jauhary, Al-Jawähir fi Tafsir al-Qur'an alKarim, (Beirut: Dār al-Fikr, t.t), Juz 6, hlm. 19; Muhammad Rasyìd Riḍā, Tafsir al-Manār, (Beirut: Dār al-Fikr, t.t), Juz II, hlm. 301-304.

${ }^{25}$ Wawancara dengan Fadzlurrahman pada tanggal 27 Ramadan 1425 H/ 10 Nopember 2004 di Universitas Madinah. Baca juga Abdullah bin Nuh, "Hanya Ada satu Djalan Bagi Umat Islam seluruh Dunia Untuk Bersatu Dalam Memulai dan Mengachiri Ramadan dan Menentukan Hari Raja Idul Fitri dan Idul Adha”, dalam AlJamiah, 5-6/Sept-Nov/1967.

${ }^{26}$ Wawancara dengan Abdul Hamy pada tanggal 27 Ramadan 1425 H/ 10 Nopember 2004 di Universitas Madinah 
$1423 \mathrm{H}$ ), dan Yusuf al-Qaradlawi salah seorang ulama dan pemikir Islam abad ini juga menyerukan penggunaan hisab dalam menetapkan awal dan akhir Ramadan, demi memperkecil perbedaan yang biasa terjadi saat memasuki awal puasa dan Idul Fitri. ${ }^{28}$ Baginya, hadis-hadis tentang rukyat harus dibaca secara situasional-kontekstual. Pada saat itu, perintah penggunaan rukyat dalam menetapkan awal Ramadan dan Syawal sangat relevan dengan kondisi masyarakat setempat. Namun, kini peradaban manusia sudah berkembang pesat dan didukung teknologi yang canggih, penggunaan hisab merupakan solusi yang terbaik. ${ }^{29}$ As-Subki dalam Fatawa-nya, sebagaimana dikutip Yusuf alQaradlawi, menyebutkan hisab adalah qath'i, sedangkan rukyat adalah zanny. ${ }^{30}$ Karena itu, bagi Muhammad Syakir, penggunaan hisab di era modern merupakan sebuah keniscayaan. Hal itu mengingat bahwa hukum tentang penetapan masuknya bulan dengan rukyat dikaitkan dengan suatu sebab (illat) yang dijelaskan oleh as-Sunnah itu sendiri. Padahal, "sebab" tersebut di masa sekarang, telah tiada lagi, dan seperti telah ditetapkan, setiap hukum berjalan bersama illah-nya, dalam keberadaannya ataupun ketiadaannya. ${ }^{31}$

${ }^{27}$ Menurut penuturan Prof. Dr. Abdul Aziz Bakrie guru besar Falak Universitas Al-Azhar Kairo-Mesir, Mesir dalam menentukan awal bulan kamariyah memperhatikan aspek astronomi dan falak syar'i serta posisi hilal saat terbenam matahari setelah terjadi ijtimak. Wawancara dilakukan pada tanggal 1 Desember 2004 di ruang Jurusan Falak Universitas Al-Azhar Kairo Mesir.

${ }^{28}$ Selengkapnya baca Yusuf al-Qaradlawi, Fiqhu as-Siyām, (Mesir: Dār al-Wafi, t.t), p. 48. Baca juga Yusuf al-Qaradlawi, Kaifa Nata'ammal ma'a as-Sunnah an-Nabawiyyah, cet. II (Kairo: Dār asy-Syuruq, 2002), hlm. 165.

${ }^{29} \mathrm{Ibid}$

31 “Sebab' (Illat) yang dimaksud adalah kemampuan umat menguasai ilmu falak (hisab). Menurutnya tidaklah masuk akal Rasulullah saw memerintahkan umat untuk menggunakan hisab pada suatu masa ketika (kebanyakan) mereka masih ummy, tidak pandai menulis dan tidak pula menghitung. Justru beliau menetapkan suatu cara yang cocok bagi mereka, ditinjau dari segi ruang dan waktu, yakni cara rukyat yang dapat dipraktekkan oleh kebanyakan orang di masa beliau. Akan tetapi, apabila telah ditemukan cara yang lebih cermat, lebih tepat dan lebih jauh dari kesalahan tidak ada satupun dalil yang melarang penggunaan hisab. Penjelasan selengkapnya baca Ahmad Muhammad Syakir, Menentukan Hari Raya dan Awal Puasa, terjemahan K.H. Mahrous Ali, cet. I, (Surabaya: Pustaka Progresif, 1993), hlm. 18-19. 
Dari uraian di atas, dapat dinyatakan baik NU maupun Muhammadiyah mengakui eksistensi hisab dan rukyat. Hanya saja, dalam tindakan etis praktis, khususnya dalam menetapkan awal Ramadan dan Syawal NU, mendasarkan pada rukyat sedangkan Muhammadiyah mendasarkan pada hisab. Artinya, bagi NU hisab hanya berfungsi sebagai "pembantu" pelaksanaan rukyatul hilal, sedangkan bagi Muhammadiyah hisab berfungsi sebagai "penentu" awal bulan kamariah. Dengan kata lain, NU cenderung pada penampakan hilal dan Muhammadiyah lebih cenderung pada eksistensi hilal.

\section{Dinamika Hubungan NU dan Muhammadiyah dalam Penggunaan Hisab dan Rukyat}

\section{Konflik}

Menurut data historis, meskipun Muhammadiyah menggunakan hisab, dalam realitasnya tidak menolak rukyat. ${ }^{32}$ Pada mulanya perbedaan metodologi antara Muhammadiyah dan NU dalam menetapkan awal bulan kamariah tidak menimbulkan konflik. Hal ini bisa dimengerti karena keputusan-keputusan yang dibuat keduanya bersifat elegan. Bahkan Muhammadiyah dalam setiap keputusannya tentang awal Ramadan dan Syawal selalu menyertai kalimat "apabila rukyat mendabului hisab maka rukyatlah yang dipakai".

Namun setelah metodologi berubah menjadi ideologi dan hisab menjadi simbol bagi Muhammadiyah dan rukyat simbol bagi NU, perbedaan-perbedaan dan konflik mulai terjadi. Dalam konteks ini, Hamka menyatakan:

Tetapi oleh karena di zaman mula2 mengembangkan tindjauan2 baru dalam negeri kita dizaman jang sudah2 terlalu banjak perselisihan disambut oleh rasa sentimen golongan, timbullah pertikaian jang panas di antara golongan pembela Hisab dengan golongan pembela rukjah. Karena itu kadang2 kaum jang membela Rukjah, walaupun sudah, ada orang melihat bulan karena penglihatan bulan itu tjotjok dengan hisab, tidak djuga mereka mau mengikut. Pernah kedjadian dalam Keradjaan

${ }^{32}$ Dalam Himpunan Putusan Tarjïh dinyatakan al-Sawm wa'l-Fitr bi'l-Ru'ya wa lā māni'a bil-Hisāa (Berpuasa dan Id Fitrah itu dengan ru'yah dan tidak berhalangan dengan hisab). 
Deli, Murid2 Syech Mahmoud Chayath melihat bulan di Belawan, melapor kepada Qadli Keradjaan Deli dihadapan Sulthan, ditjari orang berbagai dalil untuk menolak kesaksian itu. Karena kalau diakui orang melihat bulan itu, nistjaja sama Hari Raya Keradjaan dengan Hari Raya menurut Hisabnja Muhammadiyah. ${ }^{33}$

Sejalan dengan Hamka, Novel Ali menyatakan bahwa perbedaan antara hisab dan rukyat merupakan sumber konflik di kalangan Muhammadiyah dan NU. Konflik tersebut menimbulkan ketegangan dalam lembaga keluarga, karena salat Id dan lebaran tidak dilakukan pada hari yang sama. ${ }^{34}$ Menurutnya pula, akibat perbedaan antara hisab dan rukyat juga menimbulkan konflik antar berbagai kelompok masyarakat dan antara masyarakat dengan pemerintahannya.

Dari pengalaman beberapa tahun yang lalu di berbagai daerah, diketahui tumbuh suasana panas antar warga Muhammadiyah dan NU karena perbedaan awal Ramadan dan Syawal. ${ }^{35}$ Bahkan tidak jarang pemerintah bersikap "otoriter" melarang masyarakat bertakbiran keliling kota, karena menurut pemerintah keesokan harinya masih termasuk bulan Ramadan. Begitu pula larangan menyelenggarakan salat Id di lapangan atau tempat terbuka, pada hari yang belum diputuskan pemerintah sebagai hari Raya Idul Fitri. Akibatnya, pemerintah di mata kalangan NU dianggap identik dengan Muhammadiyah karena dalam menetapkan Idul Fitri selalu bersamaan dengan Muhammadiyah dan pihak NU tidak dilibatkan. Menurut K.H. Irfan Zidny, keadaan ini sangat terasa pada saat Menteri Agama dipegang oleh Munawir Sjadzali selama dua periode. Pada saat itu pertemuan-pertemuan rutin yang

${ }^{33}$ Hamka, "Rukjah dan Hisab", dimuat dalam majalah Suara Mubammadiyah, No. 10 Th. XXXIII, Syakban 1378/ Desember 1958, hlm. 13.

${ }^{34}$ Novel Ali, "Dampak Perbedaan Ru'yah dan Hisab di Tengah Masyarakat Kita", Panji Masyarakat, No. 781, 21 Syakban - 1 Ramadan, 1 - 11 Pebruari 1994, hlm. 63 - 65. Bandingkan dengan Salahuddin Wahid, "Menghormati Perbedaan: Belajar dari Kasus 'Idul Adha”, dalam Negeri di Balik Kabut Sejarah, cet. I, Jakarta: Pustaka Indonesia Satu, 2000), hlm. 136. Perhatikan pula Syamsul Arifin, "Menggagas Kembali Ukhuwah Antara Muhammadiyah dan NU", dalam Syamsul Arifin, Merambah Jalan Baru dalam Beragama, cet. I (Yogyakarta: Ittaqa Press, 2000), hlm. 273.

${ }^{35}$ Ibid. Lihat juga harian Jawa Pos, 13 Oktober 1993, p. 2; Sjamsudduha, Konflik \& Rekonsiliasi NU - Muhammadiyah, cet. I, (Surabaya: Bina Ilmu, 1999). 
diselenggarakan oleh Badan Hisab Rukyat tidak melibatkan pihak NU. Keputusan-keputusan sidang itsbat didominasi oleh hisab. ${ }^{36}$

Sebagai reaksi lahirlah rumusan keputusan Munas Alim Ulama NU di Sukorejo Situbondo pada tanggal 6 Rabiul Awal 1404/21 Desember $1983^{37}$ yang diperkuat keputusan Munas Alim Ulama NU di Pesantren Ihya Ulumuddin Kesugihan Cilacap pada tanggal 23-26 Rabiul Awal 1408/15-18 Nopember 1987, yang berbunyi: Jika pengumuman Depag tentang awal Ramadan dan Syawal hanya sematamata berdasarkan hisab, maka warga NU tidak wajib mengikuti dan menaatinya. ${ }^{38}$ Akibat keputusan tersebut tidak jarang timbul perbedaan antara NU dan Muhammadiyah dalam menetapkan Idul Fitri. ${ }^{39}$

Berdasarkan data yang terkumpul selama Orde Baru, khususnya setelah berdirinya Badan Hisab Rukyat, antara Muhammadiyah dan NU terjadi perbedaan dalam menetapkan Idul Fitri selama empat kali. Selengkapnya perhatikan grafik berikut ini.

\footnotetext{
${ }^{36}$ Wawancara dilakukan di Langkawi Malaysia, tanggal 18 Agustus 2003 M/19 Jumadal akhir $1424 \mathrm{H}$.

${ }^{37}$ Aziz Masyhuri, Masalah Keagamaan Hasil Muktamar dan Munas Ulama Kesatu 1926 s/ d Kedua puluh sembilan 1994, cet. I (Surabaya: Dinamika Press, 1997), hlm. 299. Baca juga Pengurus Besar NU, Nabdlatul Ulama Kembali Ke Kbittah 1926, cet. I, (Bandung: Risalah, 1405/1985), hlm. 41.

${ }^{38}$ Ibid, p. 327. Irfan Zidny, "Sekitar Perbedaan Awal Syawal”, Syiar, edisi Kamis 1 April 1993.

${ }^{39}$ Sebelum keputusan itu ditetapkan, NU telah mengirim surat kepada Menteri Agama agar dalam penetapan awal Idul Fitri 1407 H/ 1987 M dilakukan rukyatul hilal di tempat-tempat yang strategis. Apabila ternyata usaha rukyatul hilal tidak berhasil, NU akan menetapkan berpedoman istikmal. Selengkapnya baca surat PB NU No. 267/ B.II/07/V/1987 tertanggal 12 Ramadan 1407/ 11 Mei 1987.
} 


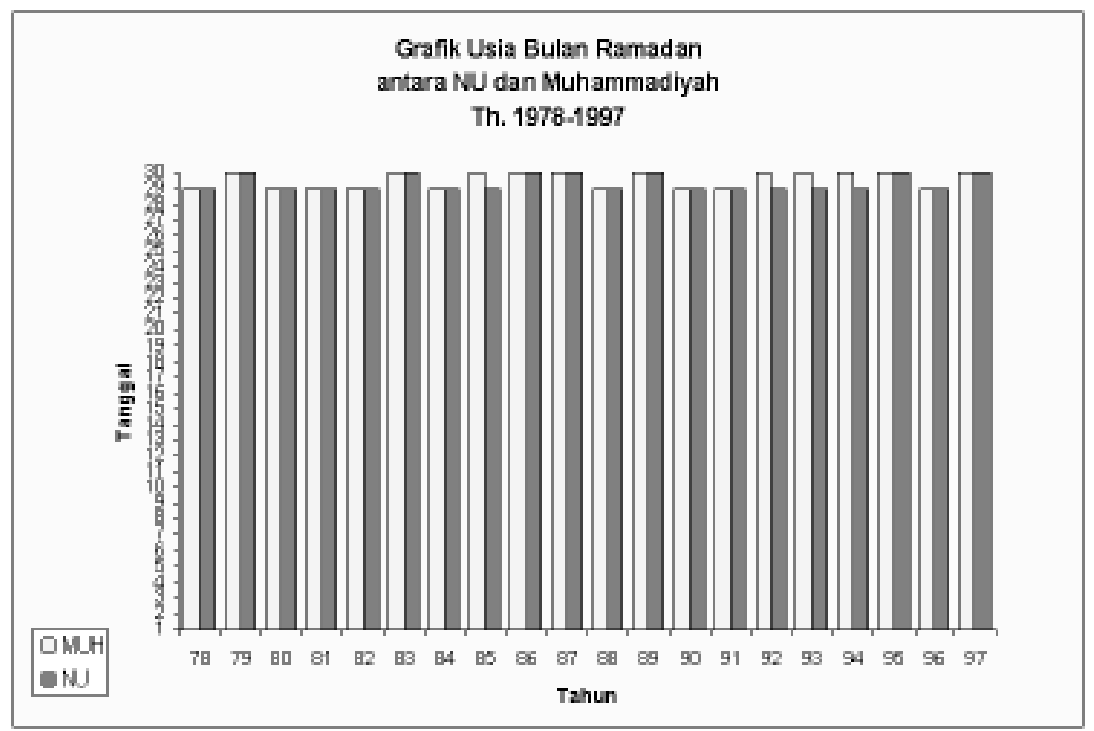

Grafik di atas menunjukkan selama dua puluh tahun, Nahdlatul Ulama melaksanakan puasa Ramadan 29 hari selama tiga belas kali dan 30 hari selama tujuh kali, sedangkan Muhammadiyah melaksanakan puasa Ramadan 29 hari selama sembilan kali dan 30 hari selama sebelas kali. Hal ini terjadi akibat perbedaan dalam menentukan awal Syawal sebagaimana dijelaskan di atas.

Mengapa kasus-kasus seperti di atas bisa terjadi? Setidaknya, dua kesimpulan dapat ditarik. Pertama, saat itu ahli rukyat sangat langka. Sedikit orang yang memahami penampakan hilal. Kesaksian rukyatul hilal yang lebih awal dari seharusnya sangat mungkin disebabkan kesalahan identifikasi. Kedua, dengan cepatnya penyebaran informasi, masyarakat menjadi bingung bila ada informasi dari negara lain yang berbeda, sementara konfirmasi rukyatul hilal setempat sangat lamban keputusannya dan masyarakat NU belum bisa menerima hisab untuk menetapkan awal Ramadan dan Syawal. ${ }^{40}$

${ }^{40}$ Baca T. Djamaluddin, "Kalender Islam Global Urgensi Masa Kini", dimuat dalam harian REPUBLIKA, 14 Februari 1994, hlm. 8. Baca juga Djohan Effendi, "Kontroversi Ru'yah dan Hisab", dimuat dalam harian KOMPAS, 10 Maret 1994, hlm. 19. Perhatikan pula Djoni N. Dawanas, "Kriteria Penampakan Hilal untuk Penentuan Awal Bulan Ramadan dan Syawal", dimuat dalam harian KOMPAS, Minggu, 29 Januari 1995. 


\section{Independensi}

Salah satu cara untuk menghindari konflik antara hisab dan rukyat adalah memisahkan dua bidang itu dalam dua kawasan yang berbeda, khususnya dalam penetapan awal Ramadan, Syawal, dan Zulhijah. Pemisahan wilayah ini tidak hanya dimotivasi oleh kehendak untuk menghindari konflik yang tidak perlu, tetapi juga keinginan untuk mengakui perbedaan karakter dari setiap area kehidupan dan pemikiran. Hal ini seperti diisyaratkan Q.S. Ar-Rum (30) : 22, yang artinya, "Dan di antara tanda-tanda kekuasaanNya ialah menciptakan langit dan bumi dan berlainan-lainan bahasamu dan warna kulitmu. Sesungguhnya pada yang demikian itu benar-benar terdapat tanda-tanda bagi orang-orang yang mengetahui."

Dalam konteks ini, Amien Rais, Ketua Pimpinan Pusat Muhammadiyah ketika itu, mengajak agar hubungan hisab dan rukyat lebih bersifat independen dan berjalan sesuai keyakinan masing-masing. Ia mengistilahkan "lakum ru'yatukum wa liya ḩisäbiy", bagimu rukyatmu dan bagiku hisabku. ${ }^{41}$ Pendapat Amien Rais ini didukung oleh Abdurrahman Wahid, ${ }^{42}$ Masdar Faried Mas'udi, ${ }^{43}$ dan Bahtiar Effendy. ${ }^{44}$

Bagi Masdar, setiap individu memiliki keyakinan dan tidak mudah dipaksakan oleh pihak lain. Dalam persoalan hisab dan rukyat pun juga demikian. Masdar juga meyakini baik Muhammadiyah maupun NU punya dasar-dasar perhitungan yang mereka yakini sendiri-sendiri, Muhammadiyah dan NU tidak mungkin asal-asalan menentukan hari raya, sebab mengandung unsur ibadah dan hukum syar'i. Itu pula sebabnya, ia meminta agar dalam menyikapi persoalan hisab rukyat dilihat sebagai hikmah. Artinya, dengan adanya perbedaan metodologi ini ummat Islam hendaknya berlomba-lomba dalam menentukan awal bulan, entah melalui hisab atau rukyat. Ini yang namanya fastabiqul khairät, berlomba dalam kebaikan, dan yang tak kalah penting adalah

${ }^{41}$ Baca harian REPUBLIKA, Rabu 14 Januari 1998.

${ }^{42}$ Dikutip dari E.M. Saidi Dahlan, "Penetapan Awal Syawal Tanggungjawab Siapa", Surya, 4 Maret 1994.

${ }^{43}$ Masdar Faried Mas'udi, "Perbedaan Idul Fitri yang Penting Harus Saling Menghormati”, Jawa Pos, Rebo Pon 28 Januari 1998, hlm. 8.

${ }^{44}$ Bahtiar Effendy, "Idul Adha", Jawa Pos, Kamis Legi 16 Maret 2000, hlm. 1, 7. 
saling menghormati. ${ }^{45}$ Sejalan dengan Masdar, Bahtiar Effendy menganggap bahwa perbedaan hisab dan rukyat sesuatu yang wajar dan hendaknya diterima dengan penuh toleransi. Baik hisab maupun rukyat merupakan cara-cara yang diajarkan Islam untuk menentukan awal bulan kamariah, seperti Ramadan, Syawal, dan Zulhijah. ${ }^{46}$

Sementara itu, A. Mustafa Bisri menganggap bahwa hisab dan rukyat merupakan dua entitas yang tidak bisa dipertemukan. Keduanya memiliki epistemologi dan metodologi yang berbeda. Karena itu, biarkan keduanya berjalan sesuai epistemologi dan metodologi yang diyakini. Muhammadiyah tidak mungkin mengubah model yang dikembangkan berdasarkan manhaj yang dimiliki. Begitu pula NU tidak mudah memalingkan nas yang telah diyakini. Ia kemudian berkeyakinan bahwa sampai kiamat perbedaan antara hisab dan rukyat tidak akan dapat dipertemukan. Selengkapnya ia mengatakan :

...Melihat "permanen" nya perbedaan semacam itu, seperti juga perbedaan-perbedaan yang lain, terutama perbedaan yang masingmasing pihak sudah merasa yakin akan kebenarannya, rasanya kok siasia mempertemukan dalam arti menyeragamkan. Insya Allah, sampai kiamat kurang dua hari, mereka yang mengikuti hisab tak akan bisa membenarkan cara mereka yang menggunakan rukyah, demikian pula sebaliknya. Kiranya tak ada satu kekuatan pun yang mampu memaksa pihak satu maupun yang lain. ${ }^{47}$

Kutipan di atas menggambarkan perasaan pesimis A. Mustafa Bisri sekaligus sikap toleran yang ingin dikembangkan. Ia menganggap perbedaan hisab dan rukyat itu seperti perbedaan selera. Dalam uraiannya ia menjelaskan :

Yang terus membuat saya heran adalah mengapa orang masih saja senang meributkan sesuatu yang jelas-jelas sulit dipersamakan semacam itu. Mengapa masing-masing masih terus bersikeras memutlakkan kebenarannya dan bersitegang menyalahkan pihak lain, bahkan tidak jarang memusuhinya? Mengapa orang tidak mau menyikapi perbedaan semacam itu sebagaimana menyikapi perbedaan selera, misalnya. ${ }^{48}$

\footnotetext{
${ }^{45}$ Ibid.

${ }^{46}$ Bahtiar Effendy, "Idul Adha", hlm. 1

${ }^{47}$ A. Mustafa Bisri, "Begitu Aja Kok Repot", Jawa Pos, Rebo Kliwon 15 Maret 2000, hlm. 7.

${ }^{48}$ Ibid.
} 
Selanjutnya, ia mengatakan jika perbedaan antara hisab dan rukyat ditanggapi seperti perbedaan selera, maka akan muncul sikap toleran dan hubungan baik antara Muhammadiyah dan NU tetap terjaga. ${ }^{49}$ Keyakinan A. Mustafa Bisri ini dapat dipahami karena budaya yang dibangun adalah "koeksistensi". Kecenderungan ini juga nampak pada Salahuddin Wahid, dalam artikelnya yang berjudul "Perbedaan, Rabmat atau Bencana?, Salahuddin Wahid mengatakan perbedaan antara hisab dan rukyat akan terus terjadi, mengingat adanya perbedaan metodologi. Baginya, yang penting perbedaan itu disikapi secara dewasa dan menjauhi sikap apriori. ${ }^{50}$ Biarkan ia berjalan seperti perbedaan penafsiran madhähib al-Arba'ah (empat mazhab) dalam persoalan fikih. Itu semua merupakan hak seseorang sebagai hamba Allah. ${ }^{51}$

Dari uraian di atas, model independensi lebih mengedepankan sikap "pasif-netral". Sikap pasif mengandung pengertian membiarkan, dan netral berarti tidak memihak, dengan kata lain hisab dan rukyat memiliki peluang yang sama. Hal ini dilakukan dengan pertimbangan pragmatis belaka bahwa lebih baik hisab dan rukyat benar-benar dipisah untuk menghindari konflik yang melelahkan. ${ }^{52}$

\section{Dialog}

Hadirnya Badan Hisab dan Rukyat merupakan salah satu upaya untuk mempertemukan kalangan hisab dan rukyat yang disimbolisasi-

${ }^{49}$ Ibid.

${ }^{50}$ Salahuddin Wahid, "Perbedaan, Rahmat atau Bencana?", REPUBLIKA, Selasa 21 Maret 2000, hlm. 8. Kecenderungan Salahuddin Wahid ini nampaknya berubah. Baca Salahuddin Wahid, "Bisakah Kalender Islam Disatukan?”, REPUBLIKA, Jum”at, 24 November 2006, hlm. 4.

${ }^{51}$ Maksum Mahfudz, "Memahami Dua Hari Raya", Surya, Jum'at 19 Maret 1993, hlm. 6.

${ }^{52}$ Perhatikan hasil penelitian André Moller, menurutnya ketika terjadi perbedaan Idul Fitri sebagian kalangan NU dan Muhammadiyah mengatakan pluralitas ialah bentuk kerahmatan. Selengkapnya baca André Moller, Ramadan di Jawa Pandangan dari Luar, cet. I, (Jakarta: Nalar, 2005), hlm. 231. 
kan antara Muhammadiyah dan NU. ${ }^{53}$ Langkah ini ditempuh oleh pemerintah dengan membentuk tim perumus yang terdiri lima orang, yaitu A. Wasit Aulawi, H. Zaini Ahmad Noeh, H. Saadoe'ddin Djambek, Susanto, dan Santoso Nitisastro. ${ }^{54}$

Ada tiga alasan yang disebutkan oleh Menteri Agama dalam pidato pengarahan pada tanggal 23 September 1972 M/ 15 Syakban 1392 H bagi proyek ini. Pertama, masalah hisab dan rukyat awal tiap bulan kamariah masalah penting dalam menentukan hari-hari besar umat Islam. Kedua, hari-hari besar itu erat sekali hubungannya dengan peribadatan umat Islam, dengan hari libur, dengan hari kerja, dengan lalu lintas keuangan dan kegiatan ekonomi di negeri ini, juga erat hubungannya dengan pergaulan hidup, baik antar umat Islam sendiri maupun antara umat Islam dengan saudara-saudara sebangsa dan setanah air. Alasan ketiga, persatuan umat Islam dalam melaksanakan peribadatan perlu diusahakan, karena dampak perbedaan itu melumpuhkan umat Islam dalam partisipasinya untuk membangun bangsa dan negara. ${ }^{55}$

Argumen-argumen di atas berkaitan dengan keyakinan kalangan Muhammadiyah dan NU tentang nash-nash yang terkait dengan persoalan Kalender Hijriah, khususnya dalam menentukan awal bulan Ramadan, Syawal, dan Zulhijah. Argumen serupa adalah keinginan menjembatani jurang pemisah antara hisab dan rukyat serta diilhami dengan kebijakan Menteri Agama yang mengajak komunitas agama di Indonesia agar saling toleran, menghormati, dan berdialog. Dari sinilah Departemen Agama menggalakkan program Pembinaan Kerukunan Hidup Beragama. ${ }^{56}$ Karena itu, Saadoe'ddin Djambek wakil pemerintah

\footnotetext{
${ }^{53}$ Sebetulnya menurut data sejarah proses dialog antara Muhammadiyah dan NU dimulai sejak dicanangkannya prinsip kembali ke Khittah 1926 dalam Muktamar NU di Situbondo. Hal ini ditandai dengan saling bersilaturrahmi antara para tokoh Muhammadiyah dengan para tokoh NU. Untuk lebih jelasnya baca Khairul Fathoni dan Muhammad Zen, NU Pasca Khittah Prospek. Ukhuwah dengan Mubammadiyah, cet. I, (Yogyakarta: Media Widya Mandala, 1992), hlm. 181-201.

${ }^{54}$ Ichtiyanto dkk, Almanak Hisab Rukyat, cet. II, (Jakarta: Ditbinbapera, 1998/ 1999), hlm. 74.

${ }^{55} \mathrm{Ibid}$, hlm. 77-78.

${ }^{56}$ Azyumardi Azra dan Saiful Umam, Menteri-Menteri Agama RI Biografi SosialPolitik, cet. I, (Jakarta: INIS, 1998), hlm. 301.
} 
melakukan kunjungan-kunjungan ke daerah-daerah, seperti Jawa Tengah, Jawa Barat, Palembang, Sumatera Barat, dan Aceh. ${ }^{57}$

Usaha ini kemudian ditindaklanjuti dengan Musyawarah Badan Hisab dan Rukyat Departemen Agama pada tanggal 5-6 Juli 1974 M/ 15-16 Jumadil akhir $1374 \mathrm{H}$. Pada pertemuan ini hadir wakil dari Muhammadiyah, NU, dan ormas-ormas Islam yang lain. Dari pertemuan tersebut disepakati untuk dilakukan pertemuan-pertemuan rutin agar dialog bisa ditumbuhkan dengan prinsip keadilan, kesejajaran, saling mengakui eksistensi masing-masing, dan berkesinambungan. ${ }^{58}$ Prinsip ini kemudian ditindaklanjuti oleh Menteri Agama Alamsjah Ratu Perwiranegara yang menerapkan kebijakan Trilogi Kerukunan Umat Beragama, yakni (1) kerukunan intern umat beragama, (2) kerukunan antar umat beragama, dan (3) kerukuan antar umat beragama dengan pemerintah. ${ }^{59}$

Untuk memantapkan kerukunan intern umat beragama, Departemen Agama mendorong para pemeluk agama untuk saling menghargai perbedaan pendapat dan aliran/ mazhab yang mereka ikuti. Upaya ini dilakukan dengan cara antara lain mempertemukan para tokoh agama dari berbagai organisasi keagamaan (seperti Muhammadiyah dan NU) untuk membicarakan hal-hal yang menjadi persoalan dasar umat, seperti persoalan penentuan awal bulan kamariah sehingga dapat dicapai kesepakatan tentang bentuk pembinaan umat. Sejalan dengan ini, umat Islam dihimbau agar menghindari hal-hal yang memicu perselisihan. Menteri Agama Alamsjah juga memperingatkan bahaya fanatisme buta yang diikuti umat, misalnya dengan mengatakan bahwa pemahaman dirinya/ alirannya saja yang benar, sedangkan lainnya salah. Klaim semacam ini dapat merusak kerukunan umat, karena hal ini berarti menganggap orang/ aliran lain sesat. ${ }^{60}$

\footnotetext{
${ }^{57}$ Ichtiyanto dkk, Almanak Hisab Rukyat, hlm. 79.

${ }^{58}$ Peunoh Daly juga berharap agar dialog antara Muhammadiyah dan NU terus ditingkatkan, khususnya dalam persoalan hisab dan rukyat. Selengkapnya baca Peunoh Daly, "Biarlah Idul Fitri Berbeda", dimuat dalam harian TERBIT, Sabtu, 20 Maret 1993, hlm. 11.

${ }^{59}$ Azyumardi Azra dan Saiful Umam, Menteri-Menteri Agama RI, hlm. 340.

${ }^{60} \mathrm{Ibid}$.
} 
Kaitannya dengan persoalan Kalender Hijriah, kebijakan Menterimenteri Agama tersebut sangat positif dan memberi warna baru hubungan Muhammadiyah dan NU. Pada periode ini masing-masing pihak saling memahami dan melakukan dialog melalui pertemuanpertemuan rutin Badan Hisab dan Rukyat dan seminar-seminar tentang hisab dan rukyat. Hal ini, misalnya, bisa terlihat dari berbagai seminar yang telah diselenggarakan di tingkat Nasional. Untuk menyebut beberapa seminar sebagai contoh, Seminar Penetapan Kaidah-kaidah Penetapan Awal Ramadan, Syawal, dan Zulbijah yang diselenggarakan pada tanggal 27 April 1992 M/25 Syawal 1412 H, Seminar Nasional tentang Penetapan Tanggal 1 Syawal yang diselenggarakan Universitas Islam Sultan Agung (Unissula) Semarang dengan narasumber K.H. Mahfudz Anwar (Pengurus Besar Nahdlatul Ulama), H. Abdur Rachim (Pimpinan Pusat Muhammadiyah), H. Wahyu Widiana (Departemen Agama RI), dan Darsa Sukartadireja (Planetarium), ${ }^{61}$ Diskusi Panel dengan tema Teknologi Rukyah Awal Bulan Ramadan dan Syawal secara Obyektif, dilaksanakan pada hari Sabtu 17 Rabiul awal 1414 H/ 4 September 1993 oleh ICMI Orsat Kawasan Puspiptek SerpongTangerang bekerja sama dengan Universitas Muhammadiyah Jakarta. Dalam diskusi ini Muhammadiyah diwakili oleh H. Basit Wahid ${ }^{62}$ dan NU diwakili oleh K.H. Ma'ruf Amin, ${ }^{63}$ Seminar Nasional tentang Hisab dan Rukyat Menyongsong 1 Syawal 1414 H di Masjid Istiqlal Jakarta, ${ }^{64}$ dan Seminar Sehari tentang Hisab dan Rukyat dalam Menetapkan 1 Ramadan, 1 Syawal dan 10 Zulhijah di Operation Room Departemen Agama RI pada tanggal 19 Agustus 1994 M/13 Rabiul awal 1415 H.65

${ }^{61}$ Harian Berita Yudha, tanggal 21 Oktober 1993, hlm. 12; harian TERBIT, 18 Oktober 1993.

${ }^{62}$ Pada saat itu H. Basit Wahid menyampaikan makalah dengan judul "Hisab untuk Menentukan Awal dan Akhir Ramadan”.

${ }^{63}$ K.H. Ma'ruf Amin menyampaikan makalah dengan judul "Ru'yah untuk Penentuan Awal dan Akhir Ramadan Menurut Pandangan Syari'ah dan Sorotan Iptek".

${ }^{64}$ Suara Karya, Jum'at, 4 Maret 1994.

${ }^{65}$ Seminar yang diselenggarakan atas kerjasama Yayasan Pendidikan Al-Huda, Badan Hisab dan Rukyat Departemen Agama, dan harian Pos Kota ini menampilkan pemakalah K.H. Ma'ruf Amin (Katib Syuriah Pengurus Besar Nahdlatul Ulama), H. Bidran Hadi (Majelis Tarjih Pimpinan Pusat Muhamamdiyah), K.H. Ibrahim Hosen, LML (Ketua Komisi Fatwa MUI), H. Taufik (Badan Hisab dan Rukyat Departemen Agama RI), Moedji Raharto (Observatorium Bosscha Bandung). 
Suasana dialogis ini juga berkembang pada saat Menteri Agama dijabat H. Tarmizi Taher. Menurut Irfan Zidny, kebijakan yang diambil Tarmizi berubah total. Sejak menjadi Menteri Agama, Tarmizi telah banyak melihat dan membaca karya-karya yang berkaitan tentang Muhammadiyah dan NU. Ternyata salah satu fenomena yang diamatinya adalah "konflik" persoalan Kalender Hijriah, khususnya dalam menetapkan awal bulan Ramadan, Syawal, dan Zulhijah. Tarmizi sependapat bahwa agama dapat menjadi salah satu kekuatan bagi umat manusia, keadilan, dan perdamaian. Sebaliknya, semangat keagamaan yang tidak toleran, tidak saling menghargai, dapat menyebabkan konflik, ketegangan, bahkan kehancuran masyarakat suatu bangsa. ${ }^{66}$

Tarmizi Taher memandang, adalah tanggungjawab warga Muhammadiyah dan NU untuk mempertahankan kerukunan, yang pada gilirannya merupakan salah satu hal penting bagi persatuan dan kesatuan. Karena itu, kebijakan yang diambil pada saat itu adalah mempertemukan Muhammadiyah dan NU dengan memberi kesempatan yang sama terhadap hisab dan rukyat. ${ }^{67}$ Untuk menciptakan dan mengembangkan kondisi seperti itu, diadakan pelatihan hisab-rukyat yang melibatkan wakil Muhammadiyah dan NU, dengan tujuan, pertama, mengkaji dan mengembangkan pemahaman tentang persoalan hisab rukyat di antara para peserta; ${ }^{68}$ kedua menyumbangkan pemikiran tentang hisab rukyat kepada pemerintah untuk membangun hubungan yang harmonis antara Muhammadiyah dan NU.

Harus diakui, wakil pemerintah yang banyak terlibat dalam proses dialog hisab rukyat antara Muhammadiyah dan NU tersebut adalah Wahyu Widiana dan Sriyatin Shodiq. ${ }^{69}$ Dalam sebuah kesempatan,

${ }^{66}$ Azyumardi Azra dan Saiful Umam, Menteri-Menteri Agama RI, hlm. 421.

${ }^{67}$ Dalam sidang Itsbat Menteri Agama selalu mendengarkan berbagai pihak. Hal ini tercermin dalam Keputusan-keputusan yang telah ditetapkan.

${ }^{68}$ Dengan pelatihan ini para peserta memperoleh wawasan yang lebih luas tentang persoalan hisab rukyat. Sebelumnya mereka hanya mengenal salah satu model hisab tapi melalui pelatihan ini dikenalkan berbagai macam model hisab, seperti Sullamun Nayyirain, Hisab Hakiki, Ephemeris Hisab Rukyat, dan Jean Meeus.

${ }^{69}$ Sriyatin Shodiq bersama Cecep Nurwendaya (Planetarium) banyak melakukan pengembangan dan modernisasi hisab dan rukyat terutama melalui pelatihan-pelatihan dan sidang itsbat. 
Wahyu Widiana menyatakan proses dialog ini membutuhkan waktu panjang dan pengertian semua pihak. Ia menyadari persoalan hisab rukyat bukan hanya masalah ilmu semata, namun sudah berubah menjadi keyakinan yang sulit diubah. Karena itu, dialog perlu dilakukan secara berkesinambungan dengan memberi informasi kepada warga Muhammadiyah dan NU tentang persoalan yang ada secara komprehensif sehingga, lanjutnya, jika masih terjadi perbedaan masyarakat sudah siap dan tidak menimbulkan konflik. ${ }^{70}$

Dalam proses dialog ini masing-masing pihak melakukan introspeksi. Muhammadiyah pasca Muktamar Banda Aceh menyadari penentuan awal Ramadan dan Syawal merupakan kegiatan rutin keagamaan Islam yang tidak bisa ditawar-tawar. Dalam hal ini ada sedikit persoalan yang tidak dibuat-buat, tetapi semata-mata karena pertimbangan ilmu pengetahuan dan teknologi ciptaan manusia itu sendiri. Era sekarang, manusia beragama dihadapkan pada komputer yang bisa menghitung, memprediksi, sekaligus melihat (ru'yah) di atas pesawat dan di layar monitor. Apakah menghitung (ḥisäb) dan sekaligus melihat (ru'yah) di atas pesawat dan di layar monitor dianggap sah, seperti jika menghitung dan melihat awal bulan dengan mata telanjang? Munculnya metode baru yang mungkin belum begitu biasa digunakan di dalam menghitung (menghisab) awal bulan Ramadan dan Syawal, merupakan salah satu tantangan baru yang juga menanti jawaban. ${ }^{71}$

Sementara itu, NU juga menyadari dalam rangka meningkatkan kemampuan dan memperluas wawasan pemikiran para ahli hisab dan rukyah di lingkungan NU, Lajnah Falakiyah diharapkan dapat melengkapi khazanah kepustakaan NU dengan berbagai karya tulis para ulama dan pakar, baik bersifat klasik maupun kontemporer. Selama ini, para ahli hisab NU hanya berpegang pada kitab-kitab klasik. Tak jarang hasil perhitungannya berbeda jauh dengan kitab-kitab hisab kontemporer. Perbedaan itu kadang-kadang melebihi satu jam untuk menentukan saat ijtimak dan tiga derajat dalam menentukan tinggi

${ }^{70} \mathrm{KOMPAS}$, Selasa, 18 Januari 1994, hlm. 10.

${ }^{71}$ M. Amin Abdullah, Dinamika Islam Kultural Pemetaan Atas Wacana Keislaman Kontemporer, cet. I (Bandung: Mizan, 1420/ 2000), hlm. 157. 
hilal, seperti hasil perhitungan awal Syawal 1412, 1413, dan $1414 \mathrm{H}^{72}$ Karena itu, kehadiran literatur-literatur kontemporer di lingkungan NU memberikan pemahaman baru sekaligus membuka ruang dialog dengan pihak lain, khususnya dengan kalangan Muhammadiyah. ${ }^{73}$ Pada saat itu, model hisab yang dikembangkan Muhammadiyah tidak banyak dipahami kalangan NU. Namun, setelah proses dialog berlangsung model hisab Muhammadiyah dipahami kalangan NU. Begitu pula, Muhammadiyah juga mengkaji tradisi hisab yang dikembangkan oleh NU. Tak kalah pentingnya, keadaan ini didukung dengan pemasyarakatan Ephemeris Hisab Rukyat dan Almanak Nautika yang dilakukan oleh Departemen Agama RI. ${ }^{74}$

Penggunaan Ephemeris Hisab Rukyat dan Almanak Nautika baik di kalangan Muhammadiyah maupun NU secara tidak langsung membangun wacana dialog dan menjembatani ketegangan intern ahli hisab. Hasil perhitungan ijtimak antara Muhammadiyah dan NU dalam menyusun Kalender Hijriah tidak berbeda jauh, kalau tidak ingin dikatakan sama. Sebagai bukti dapat diperhatikan tabel berikut ini: ${ }^{75}$

${ }^{72}$ Darsa Sukartadireja, "Tinjauan Data 1 Syawal 1414 H Dengan Acuan Hasil Hisab”, Jurnal Mimbar Hukum, No. 14, Thn. V/ 1994, hlm. 1-6.

${ }^{73}$ Sikap terbuka NU ini tidak lepas dengan gerakan "tajdid" yang dimotori Abdurrahman Wahid. Dalam Munas Cilacap Abdurrahman Wahid berbicara secara blak-blakan. Menurutnya, penting bagi kita meluaskan cakrawala NU, kalau tidak, kita akan terjebak dalam rutinitas. Cuplikan pidato selengkapnya dapat dibaca dalam Andree Feilard, NU vis-a-vis Negara Pencarian Isi, Bentuk, dan Makna, cet. I, (Yogyakarta: LKiS, 1999), hlm. 373.

${ }^{74}$ Pemasyarakatan Ephemeris Hisab Rukyat dan Almanak Nautika di lingkungan NU akan semakin cepat prosesnya bila kedua buku tersebut diterjemahkan ke dalam bahasa Arab karena masih banyak pesantren di lingkungan NU yang belum dapat menerima karya-karya yang berbahasa Inggris.

${ }^{75}$ Sumber dari Kalender Muhammadiyah dan Almanak PB NU tahun 1997 dan 1998 M. Kalender Muhammadiyah dihisab oleh Tim yang terdiri H. Abdur Rachim, Oman Fathurohman SW, dan H. Basit Wahid. Sementara itu, Almanak PB NU dihisab oleh K.H. Noor Ahmad SS. 
Karakteristik Hubungan Muhammadiyah dan Nahdlatul Ulama

Tabel. 1 Perbandingan Data Ijtimak dalam

Kalender Muhammadiyah dan NU Th. 1418 H

\begin{tabular}{|c|l|c|c|c|}
\hline \multirow{2}{*}{ No. } & \multirow{2}{*}{ Bulan } & \multicolumn{3}{|c|}{ Ijtimak } \\
\cline { 3 - 5 } & & \multirow{2}{*}{ Hari/Tgl } & \multicolumn{2}{|c|}{ Pukul } \\
\cline { 3 - 5 } & & Rabu/7 Mei 1997 & 03.47 .33 & NU \\
\hline 1 & Muhatam & Kamis/5 Jun 1997 & 14.04 .35 & 14.05 \\
\hline 2 & Safar & Sabtu/5 Jul 1997 & 01.40 .47 & 01.41 \\
\hline 3 & R. awal & Ahad/3 Agt 1997 & 15.14 .56 & 15.15 \\
\hline 4 & R. akhir & Selasa/2 Sept 1997 & 06.52 .36 & 06.53 \\
\hline 5 & J. awal & Rabu/1 Okt 1997 & 23.52 .32 & 23.53 \\
\hline 6 & J. akhir & Jum'at/31 Okt 1997 & 17.02 .04 & 17.02 \\
\hline 7 & Rajab & Ahad/30 Nop 1997 & 09.15 .01 & 09.15 \\
\hline 8 & Syakban & Senin/29 Des 1997 & 23.57 .33 & 23.58 \\
\hline 9 & Ramadan & Rabu/28Jan 1998 & 13.02 & 13.02 \\
\hline 10 & Syarwal & Jum'at/27 Feb 1998 & 00.27 & 00.27 \\
\hline 11 & Zulkaidah & Sabtu/28 Mar 1998 & 10.15 & 10.15 \\
\hline 12 & Zulhijah & & & \\
\hline
\end{tabular}

Fakta di atas menunjukkan bahwa pemasyarakatan data hisab kontemporer ke dalam lingkungan Muhammadiyah dan NU membawa hasil yang cukup signifikan. Sementara itu, dari sisi perbandingan tinggi hilal terdapat perbedaan, karena Kalender Muhammadiyah menggunakan markaz Yogyakarta (07 derajat 48 menit LS, 110 derajat 21 menit BT), sedangkan Almanak NU menggunakan markaz Jakarta (06 derajat 11 menit LS, 106 derajat 45 menit BT). Temuan di lapangan menunjukkan bahwa secara prinsipal hasil perhitungan antara Kalender Muhammadiyah dan Almanak NU sama. Hanya saja kriteria yang digunakan NU berbeda dengan Muhammadiyah. Muhammadiyah secara konsisten menggunakan teori wujudul hilal dari bulan Muharam hingga Zulhijah. Ini artinya, Muhammadiyah menggunakan standar yang jelas dan terarah. Sebaliknya NU menggunakan standar ganda dalam memformulasi Kalender Hijriah. Khusus bulan Ramadan dan Syawal digunakan teori imkanur rukyat dan ru'yat bil fi'li, sedangkan bulan-bulan yang lain seperti Muharam, Safar, dan Rabiul Awal tidak ada kriteria yang jelas. ${ }^{76}$ Untuk lebih detail, lihat tabel berikut ini:

\footnotetext{
${ }^{76}$ Pengurus Besar Nahdlatul Ulama, Pedoman Rukyah dan Hisab.
} 
Tabel 2. Perbandingan Kalender Muhammadiyah dan NU Th. 1418 H

\begin{tabular}{|c|l|c|c|c|c|c|c|}
\hline \multirow{2}{*}{ No } & \multirow{2}{*}{ Bulan } & \multicolumn{2}{|c|}{ Tinggi Hilal } & \multicolumn{2}{c|}{ Awal Bulan } & Umur Bulan \\
\cline { 3 - 8 } & & Muh & NU & Muh & NU & Muh & NU \\
\hline 1 & Muhararn & 073113 & 06.57 & $8-5-97$ & $8-5-97$ & 29 & 29 \\
\hline 2 & Safar & 015815 & 01.35 & $6-6-97$ & $6-6-97$ & 30 & 30 \\
\hline 3 & R. awal & 065335 & 07.03 & $6-7-97$ & $6-7-97$ & 30 & 30 \\
\hline 4 & R. akhir & -01625 & 10.58 & $5-8-97$ & $5-8-97$ & 29 & 29 \\
\hline 5 & J. awal & 033943 & 03.33 & $3-9-97$ & $3-9-97$ & 30 & 30 \\
\hline 6 & J. akhir & -31630 & 06.51 & $3-10-97$ & $3-10-97$ & 30 & 30 \\
\hline 7 & Rajab & -00029 & 10.35 & $2-11-97$ & $2-11-97$ & 30 & 30 \\
\hline 8 & Syakban & 032141 & 03.02 & $1-12-97$ & $1-12-97$ & 30 & 30 \\
\hline 9 & Ramadan & -50801 & 07.47 & $31-12-97$ & $31-12-97$ & 29 & 30 \\
\hline 10 & Syawal & 0034 & 00.52 & $29-01-98$ & $30-01-98$ & 30 & 29 \\
\hline 11 & Zulkaidah & 0814 & 08.56 & $28-02-98$ & $28-02-98$ & 29 & 29 \\
\hline 12 & Zulhijah & 0414 & 05.27 & $29-03-98$ & $29-03-98$ & 29 & 29 \\
\hline \multicolumn{9}{|c|}{} & \multicolumn{5}{c|}{ Total } & $\mathbf{3 5 5}$ & $\mathbf{3 5 5}$ \\
\hline
\end{tabular}

Perlu dijelaskan di sini bahwa di dalam Kalender Muhammadiyah dan Almanak NU di atas disebutkan tahun $1418 \mathrm{H}$ adalah tahun kabisat (leap year). Tahun kabisat artinya dalam satu tahun berjumlah 355 hari. Pada Kalender Muhammadiyah ditunjukkan bulan yang berusia 29 hari berjumlah 5 bulan, yaitu Muharam, Rabiul akhir, Ramadan, Zulqaidah, dan Zulhijah, sedangkan yang berusia 30 hari berjumlah 7 bulan, yaitu Safar, Rabiul awal, Jumadil awal, Jumadal akhir, Rajab, Syakban, dan Syawal. Begitu pula Almanak NU menyebutkan bulan yang berusia 29 hari berjumlah 5 bulan dan yang berusia 30 hari berjumlah 7 bulan. Hanya saja pada Almanak NU bulan Ramadan berjumlah 30 hari dan bulan Syawal 29 hari. Hal ini disebabkan karena kedua Kalender Hijriah tersebut berbeda dalam menetapkan awal Syawal.

Hal lain yang penting untuk melihat perbedaan kriteria yang digunakan Muhammadiyah dan NU adalah dengan memperhatikan data bulan Safar dan Syawal. Pada bulan Safar ketingginan hilal kurang dari dua derajat. Ini berarti belum memenuhi kriteria imkanur rukyat. Dalam prakteknya, Almanak NU sama dengan Kalender Muhammadiyah yang menetapkan awal Safar $1418 \mathrm{H}$ jatuh pada hari Jum'at bertepatan dengan tanggal 6 Juni 1997 M. Pada bulan Syawal, ketinggian hilal kurang dari satu derajat dan belum memenuhi kriteria imkanur rukyat. Namun, dalam prakteknya Almanak NU berbeda dengan kalender 
Muhammadiyah. Patut diketahui pula, dalam Almanak NU bila hasil perhitungan awal bulan menunjukkan ketinggian hilal di bawah ufuk, maka yang ditampilkan ketinggian hilal hari berikutnya, seperti bulan Rabi'ul Akhir (10.58), Jumadil Akhir (6.51), Rajab (10.35), dan Ramadan (7.47).

Di samping perhatian terhadap hisab, pada model dialog ini persoalan rukyat juga mendapat porsi yang cukup menggembirakan. Model dialog memunculkan Teleskop Rukyat sebagai alat bantu dalam melakukan rukyatul hilal. Uji coba Teleskop Rukyat pertama kali dilakukan di Pelabuhan Ratu Sukabumi Jawa Barat pada tanggal 3-5 Desember 1994 M/29 Jumadil akhir - 1 Rajab 1415 H yang diikuti berbagai ormas Islam, seperti Muhammadiyah, NU, al-Mansyuriyah, dan PERSIS. Karena itu, dengan semakin berkembangnya wacana dialog di kalangan terpelajar Muhammadiyah dan NU, ditambah lagi dengan semakin terbukanya kesempatan untuk mengakses informasi, proses integrasi dalam merumuskan Kalender Hijriah akan bisa direalisasikan.

Dengan demikian, ungkapan Mitsuo Nakamura sebagaimana dikutip Azyumardi Azra dapat dibenarkan, "These (doctrinal and organizational) conflicts (between the NU and Mubammadiyab) were already things of past", konflik doktrinal dan organisasional antara Muhammadiyah dan NU merupakan masa silam. ${ }^{77}$

\section{Integrasi}

Berdasarkan hasil wawancara dengan tokoh-tokoh NU dan Muhammadiyah menunjukkan bahwa mayoritas responden berharap hisab dan rukyat dapat diintegrasikan dengan memperhatikan kemaslahatan objektif. Dalam Munas Tarjih ke 26 di Padang Sumatera Barat diputuskan agar mengkaji persoalan penentuan awal bulan kamariah (Ramadan, Syawal, dan Zulhijah) secara terus-menerus untuk

${ }^{77}$ Azyumardi Azra, Menggapai Solidaritas Tensi Antara Demokrasi, Fundamentalisme, dan Humanisme, (Jakarta: Pustaka Panjimas, 2002), hlm. 170. Senada dengan Azyumardi Azra kalangan muda NU dan Muhammadiyah juga merasakan hal yang sama, misalnya Zuly Qadir mengatakan bahwa sebenarnya rekonsiliasi dua ormas Islam terbesar di Indonesia telah dimulai dengan sesungguhnya; Zuly Qadir, "Mempersempit Jarak Muhammadiyah-NU”, dalam Ma'mun Murod al-Barbasy dkk (ed.), MuhammadiyahNU Mendayung Ukhuwah di Tengah Perbedaan, (Malang: UMM Press, 2004), hlm. 96. 
mencari titik temu dalam membangun Kalender Hijriah Nasional. ${ }^{78}$ Begitu pula di kalangan NU berharap agar pola hubungan hisab dan rukyat saling mengisi dan mengambil model baru agar bisa dihasilkan produk penetapan awal bulan yang lebih memuaskan $;^{79}$ dengan kata lain al-akbdh bil-Jadid al-Așlah wal-Muḥäfaz̧ab 'aläl-Qadim al-Șälị̣ (meminjam istilah Abdurrahman Mas'ud). ${ }^{80}$

Moedji Raharto dalam artikelnya yang berjudul "Sumber Keragaman Penanggalan Islam" menyatakan bahwa dari segi metodologi keilmuan, hisab dan rukyat menampilkan sesuatu yang sama dengan cara berbeda. Keduanya ingin mengetahui adanya penampakan hilal. Menurutnya pula, rukyat tidak lain adalah metodologi observasi langsung, sedangkan hisab mencoba mengembangkan kemampuan akal melalui metode induksi dan deduksi untuk memahami realitas penampakan hilal yang telah diperoleh dari pengalaman rukyat. ${ }^{81}$

Begitu halnya, dua mantan Menteri Agama RI, yaitu A. Mukti Ali ${ }^{82}$ dan Munawir Sjadzali ${ }^{83}$ pernah mengungkapkan pernyataan senada, yaitu "jika rukyat dilakukan secara benar, demikian pula hisab dihitung secara tepat, maka akan menghasilkan kesimpulan yang sama,

${ }^{78}$ Hasil-hasil keputusan Munas Tarjih ke 26 di Padang

${ }^{79}$ Abd. Salam Nawawi, Rukyat Hisab Di Kalangan NU Mubammadiyah, cet. I, (Surabaya: Diantama, 2004), hlm. 43.

${ }^{80}$ Menurut Abdurrahman Mas'ud pembalikan jargon tersebut agar aswaja sebagai satu ideologi yang dinamis, tidak pernah berhenti. Pernyataan ini dimuat dalam kata pengantar dalam Muhtarom H.M., Reproduksi Ulama di Era Globalisasi, cet. I, (Yogyakarta: Pustaka Pelajar, 2005), hlm. xi

${ }^{81}$ Moedji Raharto, "Sumber Keragaman Penanggalan Islam", dimuat dalam Panji Masyarakat, No. 718 Tahun XXXIV, 28 Syawal - 7 Zulqa'dah 1412 H, 1-10 Mei 1992, hlm. 66.

${ }^{82}$ Untuk mengetahui sosok A. Mukti Ali selengkapnya baca Abdurrahman dkk., 70 Tabun H.A. Mukti Ali: Agama dan Masyarakat, cet. I, (Yogyakarta: IAIN Sunan Kalijaga Press, 1993); Azyumardi Azra dan Saiful Umam (ed.), Menteri-menteri Agama RI Biografi Sosial-Politik, cet. I (Jakarta: INIS, 1998), hlm. 269-320; Moh. Damami dkk., Lima Tokoh Pengembangan IAIN Sunan Kalijaga Yogyakarta, cet. I, (Yogyakarta: Puslit IAIN Sunan Kalijaga, 1998), hlm. 165-205.

${ }^{83}$ Tentang biografi Munawir Sjadzali dapat dibaca Muhammad Wahyuni Nafis 0(ed.), Kontekstualisasi Ajaran Islam 70 Tahun Prof. Dr. H. Munawir Sjadzali, M. A, cet. I, (Jakarta: IPHI bekerjasama dengan Paramadina, 1995); Azyumardi Azra dan Saiful Umam (ed.), Menteri-menteri Agama RI Biografi Sosial-Politik, hlm. 369-412. 
sebab hilal yang dicari hanya satu". ${ }^{84}$ Memang benar pernyataan ini, hanya saja yang menjadi persoalan adalah konsep hilal itu sendiri. Dalam kenyataannya, ternyata konsep hilal ini sangat beragam, di antaranya adalah pertama, hilal adalah bulan sabit yang dapat dilihat pertama kali dan kedua, hilal adalah bulan yang sudah lewat ijtimak. ${ }^{85}$ Konsep pertama merujuk pada ahli rukyat, sedangkan konsep kedua banyak dipakai ahli hisab. Untuk mendapatkan titik temu antara hisab dan rukyat, maka perlu dipertemukan dulu persepsi dan pemahaman tentang hilal. Penulis mengajukan kombinasi dan integrasi antara nalar literal-inderawi dan nalar rasional-ilmiah menjadi nalar integrasi-ilmiah. Adapun rumusan hilal yang diajukan dalam artikel ini adalah bulan setelah terjadi ijtimak yang secara filosofis pada saat terbenam matahari telah ada (moonset after sunset) di seluruh wilayah Indonesia. Konsep ini merupakan jalan tengah antara wujudul hilal dan imkanurrukyat (perhatikan gambar).

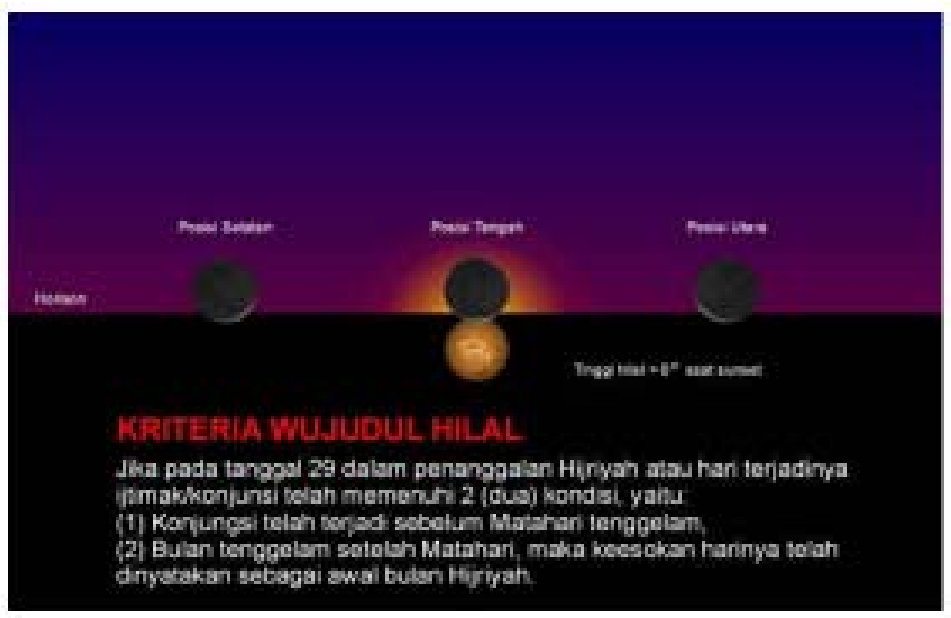

(Sumber: RHI, 2006)

Rumusan di atas diharapkan dapat mempersatukan persepsi sehingga dapat dijadikan alternatif dalam perumusan Kalender Hijriah.

\footnotetext{
${ }^{84}$ Lihat majalah Risalah, No. I/ XXXII Maret 1994.

${ }^{85}$ Dengan catatan pertama, asal ijtimak terjadi sebelum terbenam matahari (sunset) dan kedua, asal bulan di atas ufuk pada waktu terbenam matahari setelah ijtimak
} 
Nalar integrasi ilmiah lebih menjanjikan dan memungkinkan untuk jangka pendek. Karena itu, paradigma yang ingin dikembangkan lebih bersifat filosofis. Artinya, nalar integrasi ilmiah merupakan sintesa antara paham rasional dengan paham realis-empiris yang mengharuskan adanya riset-riset berkelanjutan dengan memfokuskan pada wilayah Indonesia sehingga teori yang dibangun bukan semata-mata mengadopsi dari negara-negara lain, tetapi merupakan realisasi hasil konstruksi negeri sendiri. ${ }^{86}$ Dengan kata lain, nalar integrasi ilmiah merupakan "jalan tengah" antara wujudul hilal dan imkanur rukyat.

Kriteria nalar integrasi ilmiah sebenarnya merupakan titik temu antara metode hisab dan rukyat. Ahli rukyat (NU) terus melakukan rukyatnya dengan dipandu data-data hasil hisab. Ahli hisab (Muhammadiyah) dipersilahkan terus menghisab tanpa melupakan pengalaman rukyat. Persoalannya, titik temu itu belum berupa titik yang tunggal. Menurut T. Djamaluddin, khusus di Indonesia titik temu itu ada tiga : kriteria wujüdul hiläl, kriteria MABIMS, dan kriteria Internasional. Menyatukan ketiganya adalah hal yang mungkin, hanya perlu waktu dan melebarkan tingkat toleransi semua pihak. ${ }^{87}$ Selanjutnya T. Djamaluddin menyatakan :

Bila benar keberatan tokoh Muhammadiyah untuk menerima kriteria MABIMS hanya karena anggapan kriteria itu tidak punya dasar ilmiah astronomis adalah dasar organisatoris, maka tinggal satu langkah untuk menyatukan titik temu itu di Indonesia. Langkah itu adalah kaji ulang kriteria MABIMS dengan analisis astronomis dengan data asli Indonesia. ${ }^{88}$

Ungkapan di atas mengisyaratkan bahwa teori imkanur rukyat dirumuskan secara deduktif an sich karena kaji ulang yang dilakukan hanya mendialogkan antara teori MABIMS dengan data-data hasil

\footnotetext{
${ }^{86}$ Sudah saatnya LIPI dan Balitbang Depag RI melakukan studi bersama tentang persoalan ini.

${ }^{87}$ Selengkapnya baca T. Djamaluddin, "Menyatukan "Dua Idul Fitri”, dimuat dalam harian REPUBLIKA, 4 Desember 2002, hlm. 4.

${ }^{88}$ Ibid. Baca juga Fahmi Amhar, "Fakta Hisab, Rukyat, dan Rukyat Global", makalah disampaikan pada Workshop Nasional Metodologi Penetapan Awal Bulan Qamariyah Model Muhammadiyah, tanggal 19 Oktober 2002 di Universitas Muhammadiyah Yogyakarta, hlm. 1.
} 
rukyatul hilal di Indonesia tanpa didukung hasil observasi mandiri. Hal ini tergambar pada teori LAPAN yang diintrodusir oleh T.Djamaluddin. ${ }^{89}$ Pada teori LAPAN ini dinyatakan bahwa imkanur rukyat terjadi bila umur hilal minimum 8 jam, jarak sudut bulan matahari minimum 5,6 derajat, beda tinggi minimum 3 derajat (tinggi hilal minimum 2 derajat) untuk beda azimut sekitar 6 derajat. Untuk beda azimut kurang dari 6 derajat perlu ketinggian yang lebih besar. Untuk beda azimut 0 derajat, beda tingginya minimum 9,1 derajat (tinggi hilal 8 derajat)..$^{90}$

Bagi Muhammadiyah, teori LAPAN sebagai produk ijtihad patut dihargai tapi masih sulit diterima karena teori tersebut tidak empiris. Abdur Rachim-salah seorang ahli hisab Muhammadiyah-menyatakan jika teori imkanur rukyat hanya dibangun dan dirumuskan berdasarkan data-data masa lalu yang masih dipertentangkan keakuratannya, maka teori tersebut tidak memiliki basis epistemologis yang kuat. Jika yang terjadi demikian maka wujūdul hilāl masih relevan untuk dijadikan pedoman dalam penetapan awal bulan kamariah. ${ }^{91}$

Selama ini, Muhammadiyah dan NU berjalan sendiri-sendiri karena masing-masing mengembangkan paradigma yang dimiliki. Akibatnya, tak jarang memunculkan perbedaan dalam menetapkan awal Ramadan, Syawal, dan Zulhijah. Hal itu dikarenakan rukyatul hilal sangat sulit. Taufiq Ismail melukiskan hal tersebut dalam salah satu syairnya yang berjudul "Bulan, Apa Betul itu, Kau Sulit Dilihat ?". 92

${ }^{89}$ Data pengamatan hilal diambil dari Himpunan Keputusan Menteri Agama tentang Penetapan Tanggal 1 Ramadan dan 1 Syawal 1381-1418 H/ 1962-1997 M. Ada 38 pengamatan rukyatul hilal yang dilaporkan dalam selang waktu tersebut. Depag RI, Himpunan Keputusan Menteri Agama tentang Penetapan Tanggal 1 Ramadan dan 1 Syawal Tabun 1381-1418 H/ 1962-1997 M, cet. I, (Jakarta: Direktorat Pembinaan Badan Peradilan Agama Islam, 1999/2000).

${ }^{90}$ T. Djamaluddin, "Menyatukan "Dua Idul Fitri", hlm. 4.

${ }^{91}$ Wawancara dengan H. Abdur Rachim di Jakarta pada tanggal 31 Agustus 2003. Pendapat ini juga berkembang di kalangan Muhammadiyah, misalnya pada Munas Tajih ke-26 di Padang. Karena itu, Muhammadiyah tetap menggunakan teori wujudul bilal dalam menetapkan awal bulan kamariah.

${ }^{92}$ Syair ini ditulis hari Rabu, 14 Ramadan 1420/ 12 Desember 1999, 17.20, Masjidil Haram, dimuat dalam harian REPUBLIKA, Sabtu, 15 Desember 2002. 
Syair Taufiq Ismail di atas bukan hanya indah, tetapi menginsafkan pola pikir parsial-dikotomis. Dalam rukyat sering terjadi bahwa secara kaidah ilmu pengetahuan "hilal tidak visibel" namun menurut pengakuan "pengamat hilal", hilal dapat disaksikan. ${ }^{93}$ Kesaksian melihat hilal saat posisi bulan di bawah horison (ufuk) merupakan kejadian cukup untuk menjadi petunjuk bahwa realitas pengamatan hilal belum diperiksa oleh "hakim" atas dasar ilmu hisab tentang visibilitas hilal. Dalam konteks ini, Moedji Raharto menuturkan pengalamannya sebagai berikut.

Pengalaman saya ketika menghadiri rukyatul hilal di Pelabuhan Ratu 23 Maret 2001 yang lalu menarik, tidak ada tim pengamat hilal Depag RI yang menyaksikan hilal saat itu. Salah seorang muslim (KHAK) yang tak disangsikan kesalehannya di antara hampir 100 orang yang hadir di lokasi tersebut menyatakan melihat hilal. Saat ditanya tentang bentuk hilal akhirnya diputuskan bahwa apa yang disangka hilal oleh pengamat hilal itu disimpulkan bukan hilal, kemungkinan besar awan tipis menyerupai bentuk sabit bulan. Tim Depag dan hakim setempat tidak mengambil sumpah kesaksian pengamat hilal (KHAK). ${ }^{94}$

Pengalaman Moedji Raharto di atas bukanlah satu-satunya, penulis juga pernah mengalami hal yang sama. Oleh karena itu, kriteria hisab cum rukyat merupakan kriteria jalan tengah. Kalangan Muhammadiyah yang berpendapat cukup dengan hisab (wujudul hilal) tidak mungkin lepas dari kriteria hisabnya. Kalangan NU yang berpendapat harus ru'yat bi al-fili semestinya memiliki kriteria rukyat untuk menerima atau menolak kesaksian bukan sekedar sumpah. Dengan kata lain, kedua belah pihak sama-sama maju. Bila hal ini terjadi, maka unifikasi Kalender Hijriah Nasional bukan sebuah utopia.

Pekerjaan ini membutuhkan keseriusan dan kesadaran objektif di kalangan umat Islam, khususnya para elite Muhammadiyah dan NU.

${ }^{93}$ Perhatikan kasus Idul Adha $1425 \mathrm{H}$ di Saudi Arabia. Secara teoretis (hasil perhitungan) pada hari Senin 10 Januari 2005 di Saudi Arabia posisi hilal pada saat terbenam matahari masih di bawah ufuk. Kenyataannya ada beberapa saksi yang melihat hilal pada malam Selasa, yaitu dari As-Sih di Sebelah Timur ar-Rain; Tempo, Selasa 18 Januari 2005, hlm. 14.

${ }^{94}$ Moedji Raharto, "Realitas Visibilitas Hilal”, REPUBLIKA, Jum'at, 16 November 2001, hlm. 16. 
Tanpa keseriusan dan kesadaran objektif nampaknya sulit diwujudkan. Masing-masing pihak seharusnya menyadari bahwa perumusan Kalender Hijriah, terutama penetapan awal Ramadan, Syawal, dan Zulhijah adalah bersifat ijtibadi. Muhammadiyah dan NU harus secara terbuka mengkaji ulang kriteria yang digunakannya. Masing-masing memiliki kekurangan dan kelebihan yang bila dikaji lagi terbuka peluang untuk mendapatkan solusi yang "tunggal" yang dapat diterima semua pihak dengan sikap gentleman agreement (meminjam istilah Alwi Shihab), yakni antara Muhammadiyah dan NU siap menerima apa yang disepakati.

\section{Penutup}

Hubungan NU dan Muhammadiyah dalam menggunakan hisab dan rukyat, saat menentukan awal bulan kamariah (awal Ramadan dan Syawal) memiliki model beragam, yaitu konflik, independensi, dialog, dan integrasi.

Selanjutnya, dari empat model hubungan NU dan Muhammadiyah dalam menggunakan hisab dan rukyat di atas, dapat dinyatakan bahwa munculnya model independensi tidak berarti ciri-ciri model konflik telah hilang sama sekali, sama halnya kehadiran model dialog tidak serta merta ciri-ciri model konflik dan independensi berakhir. Begitu pula kemunculan model integrasi tidak berarti ciri-ciri model sebelumnya juga tidak ada. Dengan kata lain, tipologi hubungan NU dan Muhammadiyah dalam menggunakan hisab dan rukyat lebih bersifat teoritis, pada wilayah empiris terjadi tumpang tindih antara model yang satu dengan model lainnya. 


\section{BIBLIOGRAFI}

Abdullah, M. Amin, Dinamika Islam Kultural Pemetaan atas Wacana Keislaman Kontemporer, cet. i, Bandung: Mizan, 2000.

Abdurrahman dkk., 70 Tabun H.A. Mukti Ali : Agama dan Masyarakat, cet. I, Yogyakarta: IAIN Sunan Kalijaga Press, 1993.

Abdurrahman, Asjmuni, Manbaj Tarjïh Mubammadiyah Metodologi dan Aplikasi, cet. II, Yogyakarta: Pustaka Pelajar, 2003.

Ad-Difa', 'Ali 'Abdullah, 'Tlmu al-Falake fi al-Hadärab al-'Arabiyyah alIslämiyyah, cet. II, Riyad: Maktabat al-Tawbah, 1993 M/1414 H.

Ali, A. Yusuf, The Holy Qur'an: Text, Translation and Commentary, Riyad: Amana Corp, $1403 \mathrm{H}$.

Anam, Choirul, Pertumbuban dan Perkembangan Nabdlatul Ulama, Solo: Jatayu, 1985.

Asy'ari, Hadratussyaikh Hasyim, Ablussunnah wal Jama'ah, terj. Khoiron Nahdliyin, cet. I, Yogyakarta: LKPSM, 1999.

Aulawi, A. Wasit, Laporan Musyawarah Nasional Hisab dan Rukyat Tahun 1977, Jakarta: Ditbinbapera, 1977.

Azra, Azyumardi dan Saiful Umam (e.d), Menteri-menteri Agama RI Biografi Sosial-Politik, cet. I, Jakarta: INIS, 1998.

Badan Meteorologi dan Geofisika, Garis Ketinggian Hilal 0 Pada Awal Bulan Qomariah Tabun 1426/1427 H (2006), Jakarta: Badan Meteorologi dan Geofisika, 2005.

Dahlan, Abdul Aziz, Ensiklopedi Hukum Islam, cet. I, Jakarta: PT. Ichtiar Baru Van Hoeve, 1997.

DIZER, Muhammad, A Calculation Method for the Visibility Curve of the New Moon, Kandili Observatory, 1983.

Djamaluddin, T, "Menyatukan "Dua Idul Fitri", REPUBLIKA, 4 Desember 2002.

Effendi, Djohan, “Kontroversi Ru'yah dan Hisab”, KOMPAS, 10 Maret 1994.

Encyclopaedia Britannica, London: William Benton Publisher, 1965. 
Esposito, John L, The Oxford Encyclopaedia of The Modern Islamic World, cet. I, New York: Oxford University Press, 1995.

Fealy, Greg, Ijtihad Politik Ulama Sejarab NU 1952-1967, cet. I, Yogyakarta: LKiS, 2003.

Hadikusuma, Djarnawi, "Mengapa Muhammadiyah Memakai Hisab?", Suara Muhammadiyah, No. I, Dzulhijjah 1392/ Januari 1973.

Hayat, Sholeh, "Integrasi Hisab dengan Rukyat", Jawa Pos, Rabo, 6 November 2002.

Ilyas, Mohammad, A Modern Guide to Astronomical Calculations of Islamic Calender, Times \& Qibla, Kuala Lumpur: Berita Publishing, 1984.

—, Islamic Astronomy and Science Development Glorious Past, Challenging Future, Malaysia: Pelanduk Publication, 1996.

Ilyas, Yunahar dkk (ed.), Muhammadiyah dan NU Reorientasi Wawasan Keislaman, Yogyakarta: LPPI UMY, LPKSM NU dan PP Al-Muhsin, 1993.

Izzuddin, Ahmad, Fiqh Hisab Rukyah di Indonesia, Yogyakarta: Logung, 2003.

King, David A, Islamic Astronomical Instruments, London: Variorum, 1987. 